Manuscript $\mathrm{B} b$ is kept in the Royal library of Berlin, with the shelfmark 229 ( $\mathrm{Sa}$ chau 194); 295 paper folios (0.32 x 0.22), in two columns. It was completed on the sixth day of November, I882, by the same 'Abd al-'Aziz. The incipit gives the name of Bar 'Ali, but Bar 'Ali's preface is lacking. See Sachau, Verzeichness der syr. Handschr. zu Berlin, 7 II.

Manuscript B $b b$ is kept in the same library of Berlin, with the shelfmark 228 (Sachau 305, not 395, as was erroneously printed in the preface to the first fascicule, p. ii above), 508 folios (0.33 x 0.23). It was completed on the seventh day of June, I839, by David the elder. But Sachau has claimed that David the elder was (in fact) two scribes, the later of whom did not live much after the earlier. Arabic glosses are written in Syriac script. Syriac and Arabic versions of Bar 'Ali's preface (are given) at the beginning, as in manuscript L, but the short note carries the name of David the elder, where the name Abraham is written in manuscript L and other manuscripts (cf. above, ix, 1. 24). See Sachau, Verzeichness der syr. Handschr. zu Berlin, 7ıо.

Manuscript Bbbb is kept in the same library, with the shelfmark 230 (Sachau I7I); 342 folios ( $0.33 \times 0.23$ ), in two columns, written in year 1883 by the 'Abd al-'Aziz mentioned above (see manuscripts $\mathrm{L}$ and $\mathrm{B} b$ ). It contains no preface. See Sachau, Verzeichness der syr. Handschr. zu Berlin, 712.

The copies which Bernstein arranged to be prepared from several manuscripts kept in European libraries were deposited in the Royal library of Berlin with the shelfmark 227 (Ms. Orient., 542-544), as we said in the preface to the first fascicule, page iv above. These include: $\mathrm{A}$, a copy of manuscript $\mathrm{H}$, containing Ioor pages, copied in the year 1836 , (pages $873-882$ of the manuscript being omitted; B, a copy of the first half of manuscript M (letters $\lrcorner-\Omega$ ), with the additional collation of manuscript $F$ in green and manuscript $\mathrm{C}$ in red, containing 7or pages, in two columns, written in the years 1836 and 1837 ; $C$, with parts of the same manuscript F (letters $\boldsymbol{\phi}, \boldsymbol{\Omega}, \boldsymbol{\Sigma}$, and $\boldsymbol{\text { r }}$ ), written in II9 pages. Cf. Bernstein, Z. D. M. G., II, 37I; Sachau, Verzeichness der syr. Handschr. zu Berlin, 709 .

\title{
VI. ON THE SYRIAC AND ARABIC PREFACES OF BAR BAHLUL
}

It is clear from the descriptions given in the previous section of the manuscripts of the lexicon available to us that Bar Bahlul's prefaces are only found in manuscripts BHRSs. Having collated these manuscripts with one another, we may relate that the texts (of these prefaces) are printed at the beginning of the edition (col. I-4), the Latin translations of which are given on pages xi-xii of this introduction, above. 